\title{
ACTIVE SENSOR ALGORITHM APPROACH TO OPTMIZE NITROGEN RATE FERTILIZATION IN COTTON PRODUCTION
}

Jonnas De Marchi ${ }^{(1)}$, Ziany Neiva Brandão ${ }^{(2)}$, Thiago Martins Machado ${ }^{(1)}$, Luciano Shozo

$$
\text { Shiratsuchi*(3) }
$$

(1) Universidade Federal de Mato Grosso.tm.machado@hotmail.com

(2) Embrapa Algodão. Research and Development. ziany.brandao@embrapa.br

(3) Louisiana State University AgCenter, School of Plant, Environmental and Soil Sciences.

LShiratsuchi@agcenter.lsu.edu

*Corresponding author

\begin{abstract}
Variable nitrogen(N) rate fertilization based on remote sensing is challenging for cotton production fields, but active crop canopy sensors (ACS) appear as an alternative to make this practical on farm since they can be used at night as well. The crop spatial variability in inherent in crop production in general, and not on-the-go solutions can be used with this type of active sensing technologies. Thus, the purpose of this study was to investigate the potential of two vegetation indices to identify the $\mathrm{N}$ requirement variability for cotton plants and to develop prototype algorithms for topdressing nitrogen variable rate on commercial and experimental areas, using the N-sufficiency methodology based on virtual reference. The concept of virtual reference is to use a histogram to characterize the vegetation index of properly fertilized plants without establishing an $\mathrm{N}$-rich plot as a reference strip. The experiment was conducted in strips with four different $\mathrm{N}$ rates $\left(0,45,90\right.$ and $\left.180 \mathrm{kgN} \mathrm{ha}^{-1}\right)$ during the 2015, 2016, 2017 and 2018 crop seasons in partnership with large cotton producers in Mato Grosso and also in experimental area of Embrapa Agrosilvopastoral. Two algorithms for variable rate nitrogen fertilization for cotton were developed, namely: 1) $\mathrm{N}$ recommendation algorithm for cotton in commercial production system: $\mathrm{N}$ rate $\left(\mathrm{kg} . \mathrm{N} \mathrm{ha} \mathrm{h}^{-1}\right)=-$ 234.79 ISN ${ }^{2}+49,879 \mathrm{ISN}+195.15 ; \mathrm{R}^{2}=0.97 ;$ and 2) for cotton grown in experimental area: $\mathrm{N}$ dose $\left(\mathrm{kgN} \mathrm{ha}^{-1}\right)=-174.73 \mathrm{ISN}^{2}-107.21 \mathrm{ISN}+306.78 ; \mathrm{R}^{2}=0.94$.
\end{abstract}

Keywords: precision agriculture, active crop canopy sensors, proximal remote sensing, variable rate fertilization 


\section{Introduction}

Nitrogen fertilization management is a challenge for different agricultural crops, specially because it is a nutrient with complex dynamics in the soil, related to several loss mechanisms (denitrification, volatilization, runoff, leaching, etc.) and so, a potential cause of environmental impacts. Nitrogen Use Efficiency (NUE), badly reach 60\% for most cultures, like cotton and grains (ANTILLE \& MOODY, 2021; CANTARELLA, 2007). NUE value can vary between seasons and fertilizer application form, to specific cropping systems, as shown in BELL et al. (2014) and CONNELLAN\&DEUTSCHENBAUR (2016) for sugarcane.

Currently practices on nitrogen management to cotton production systems in Brazil generally include remarkable amounts of $\mathrm{N}$, generally applied through uniform rates at early phenological stages when the plant is not absorbing the nutrient causing lower efficiency of use of nitrogen fertilization. Considering that the expenses with fertilizers correspond to, on average, about $22 \%$ of the total cotton production costs (ANSELMO et al., 2011), nitrogen fertilization in cotton should be carried out cautiously, since its proper use can lead to higher profitability and less impact in the Environment.

Moreover, precision farming techniques have been explored to increase efficiency of the agricultural inputs, the use of ACS for an accurately and helpful information to crop management with high spatial resolution, allowing precise detection and adjustments of $\mathrm{N}$ fertilization on heterogeneous fields still scarce.

The basics of ACS is the fact that spectral properties (reflectance and transmittance) of the crop canopy are affected by the availability of chlorophyll accumulation in plant leaves, directly related with nitrogen (N) content (BLACKMER et al., 1996; TARPLEY et al., 2000; SHIRATSUCHI et al., 2014).

One of the main advantage of these sensors is the possibility to use embedded in agricultural machines capable of on-the-go or real-time $\mathrm{N}$, considering the spatial and temporal variability of the $\mathrm{N}$ requirement, avoiding losses and, consequently, increasing profitability. But there is no practical algorithms generated for cotton production in major states in Brazil such as MT, BA and GO.

In recent years, several researchers have been dedicated to the spectral bands study to suggest high sensitivity vegetation indices (VIs) for estimate $\mathrm{N}$ content in crops. The main goal of these studies is to manage properly $\mathrm{N}$ supply with fitted algorithms, specially due to saturation presented in some vegetation indices (VIs), such as the normalized difference vegetation index (NDVI), whose occurrence is affected by high level of chlorophyll contents 
presented in canopy, generally perceived as high values of the leaf area index (LAI) (GITELSON et al., 1996; HABOUDANE et al., 2004). High LAI values promotes high nearinfrared response, the red band is not so responsive, causing NDVI insensitivity to changes in chlorophyll content for very high $\mathrm{N}$ rates. As a plant intrinsic characteristic, cotton keep on high biomass accumulation rate in early stages, being prone to NDVI saturation when the crop is sensed to be fertilized using these ACS.

Commercial sensors have been used in Brazil with algorithms developed in other countries such as the USA, Australia or Europe, requiring the local calibration of these formulations or even a new one to be build up for cotton growing conditions in the Brazilian "Cerrados". Most of the algorithms adjusted for Brazil use laboratory calibration procedures that require a lot of effort or are based on unrepresentative locations, in addition to being identified to the crop conditions (variety and phenology) in which they were calibrated. Several factors can affect vigor and demand for $\mathrm{N}$ in the crop, such as genetic differences between cultivars, different phenological stages, climate, base fertilization and cultural practices, making it necessary to study practical methodologies that mitigate these effects.

In Brazil, there is a great lack of methodologies based on active canopy sensors to direct the application of $\mathrm{N}$ at variable rates in cotton production systems in both approaches (map-based or on-the-go).

Based on this context, the present work aimed to investigate the sensitivity of two vegetation indices to identify the $\mathrm{N}$ requirement variability, as well as to develop a first prototype algorithm.

\section{Material and Methods}

The experiment was conducted in four growing seasons, since 2015 up to 2018. During 2015 season, the experiment was conducted on farm with cooperating producers located at Lucas do Rio Verde, Sinop, Campo Verde and Sapezal regions, and in the 2016, 2017 and 2018 seasons at Embrapa, in an experimental area located in Sinop - MT (55³5'42"W ; 11 52 '30"S, WGS84).

Before setting up the experiments, typical cotton producers were selected in Mato Grosso (MT) state of Brazil. The main criteria for selection was the adoption of no tillage system in succession with cotton, particularly those producers using the soybean crop as the first crop and cotton in succession, because this is the predominant used in cotton production in MT. 
The region climate, according to Köppen-Geiger classification, is Aw's tropical, characterized by high temperature, with average of $25^{\circ} \mathrm{C}$, and well distributed rainfall at summer and fall. The average rainfall on crop season is $880 \mathrm{~mm}$. In general, the soil is classified as Dystrophic Red-Yellow Latosol, with a predominantly clayey texture (SANTOS et al, 2013).

On the experimental fields conducted in commercial farms, each plot consisted of long strips, considering fertilizer applicator width by the field length that varied from field to field. In all experimental plots, the cotton sowing was performed between January 14 and February 18, 2015, with the FM 975 WS variety suing $0.75 \mathrm{~m}$ row spacing. The starter/base fertilization at planting or close was made using $500 \mathrm{~kg} \mathrm{ha}^{-1}$ of 08-20-20 formula. It was used potassium fertilization (140 $\mathrm{kg} \mathrm{K} \mathrm{ha}^{-1}$ ), divided into two applications, with potassium chloride as a source. The treatments consisted of four $\mathrm{N}$ doses $\left(0,45,90\right.$ and $\left.180 \mathrm{~kg} \mathrm{~N}^{-1}\right)$ replicated 3 times and randomized in transect. Nitrogen was applied into two side-dress applications, between 30 and 45 days after plant emergence (DAE), using urea granule fertilizer.

In 2016, 2017 and 2018, the experiment was conducted inside Embrapa experimental

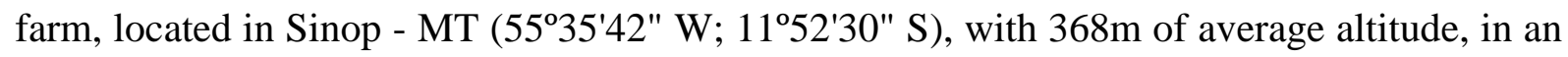
area with previous soybean-corn succession, at least in the last two years preceding the conduction of the experiment. The soil is classified as Dystrophic Red-Yellow Latosol with a predominantly clayey texture (SANTOS et al, 2013). Soil sampling was carried out in the experimental area to determine soil fertility (Table 1).

Table 1. Soil chemical attributes in the experimental areas.

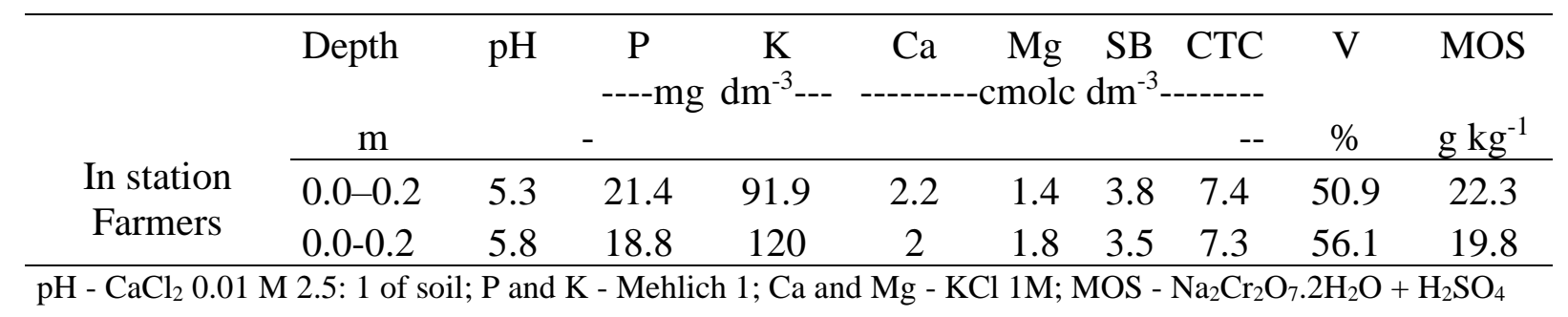

The region's climate, according to the Köppen-Geiger classification, is of the Aw type, tropical, with a rainy season in the summer and a dry season in the winter. Average temperature and precipitation is the same of provided in the first year experiments performed into producers area. 
The experiment was carried out in experimental plots, where each plot consists of long strips with six rows of plants, spaced at $0.90 \mathrm{~m}$, and $60 \mathrm{~m}$ long $\left(324 \mathrm{~m}^{2}\right)$. The two central rows were considered as a useful area for the evaluations, discarding the other lateral rows as buffer, to reduce the effect of fertilizer dispersion at the time of application.

The sowing was carried out on January 14, 2016, February 20, 2017 and February 17, 2018, using the varieties BRS369RF, IMA 5675 BG2RF and FM 940 GLT, respectively, in a spacing of $0.9 \mathrm{~m}$ with a $08-20-20$ formula in 2016 as base fertilization with $450 \mathrm{~kg} \mathrm{ha}^{-1}$, and $350 \mathrm{~kg} \mathrm{ha}^{-1}$ of 04-30-16 formula for the other years. Potassium fertilization (140 kg K ha-1) was broadcast uniformly in side-dress, divided into two applications, at 30 and 45 DAE, using potassium chloride as a source. The treatments consisted of four $\mathrm{N}$ rates $(0,45,90,180 \mathrm{~kg} \mathrm{~N}$ $\mathrm{ha}^{-1}$ ) with four randomized replicates, totaling 16 plots. Nitrogen was applied in top dressing, divided in two applications, between 30 and 45 DAE, using urea fertilizer as source.

Diseases and pest control was carried out in accordance with Embrapa standards, as described by EMBRAPA (2001), uniformly in all treatments.

To evaluate the canopy reflectance, it was used an active sensor Crop Circle, model ACS-430 (Holland Scientific ${ }^{\circledR}$, Lincoln, NE, USA). The target reflectance is captured by three photodetectors, in the electromagnetic spectrum regions: 670, 730 and 780, corresponding to Red, Red-edge, and NIR (near infrared band), respectively. The device field of view is 32 by 6 degrees, with a recommended working height between 0.25 and $2.0 \mathrm{~m}$ in relation to the target, equivalent to a sensed range of 0.5 and $1 \mathrm{~m}$, respectively.

Reflectance readings were carried out after the first $\mathrm{N}$ application, at 35 DAE (2015) for partner experiments and at 36 DAE (2016), 32 DAE (2017) and 37 DAE (2018) for experimental plots in Embrapa, corresponding to phenological stage V5. The sensor was used as a handheld device, walking between rows at constant speed $\left(0.75 \mathrm{~ms}^{-1}\right)$ and height about $0.6 \mathrm{~m}$ from the canopy, recording data at a frequency of $1 \mathrm{~Hz}$, being considered readings average as the real value of each plot.

To evaluate the cotton yield, the harvest was made manually in both cultivation systems, considering as useful area the two central rows with $3 \mathrm{~m}$ of length per plot.

Nitrogen application algorithms developed in this work use the methodology suggested by Schepers et al., 1992, called the sufficiency index (SI). This methodology normalizes the vegetation index (VI) sensed by an average VI derived from a reference plot considered non-limiting for $\mathrm{N}$. usually called $\mathrm{N}$ rich strip.

Many studies have reported that the SI is better than the absolute reading value of any sensor for assessing $\mathrm{N}$ status in crops, as this concept integrates into the sensor readings the 
effects of climate, soil, hybrids, canopy structure (plant development stages and leaf architecture), for different crops (PETERSON et al., 1993; HUSSAIN et al., 2000; DEBAEKE et al., 2006; HOLLAND \& SCHEPERS, 2010; ZHU et al., 2011).

The normalization process consists of dividing the sensor readings by the N-rich average, resulting in a quotient called SI (Eq. 1), which is mathematically described as:

$$
S I=\frac{V I_{\text {sensor }}}{V I_{\text {reference }}}
$$

where, $S I$ is the sufficiency index $(0 \leq S I \leq 1), V I_{\text {sensor }}$ is the real-time measured vegetation index, and $V I_{\text {reference }}$ is the vegetation index on the $\mathrm{N}$ rich area.

In fact, the SI calculation can be applied to any VI or crop parameter evaluated, allowing the comparison between different VIs or parameters. This concept is used extensively with yield monitor data, called normalized yield. In this work, the potential of two VIs was investigated without $\mathrm{N}$ requirement variability identification for cotton. They are: (i) normalized difference vegetation index (NDVI) developed by Rouse et al., (1974), mathematically described as:

$$
N D V I=\frac{\rho N I R-\rho R E D}{\rho N I R+\rho R E D}
$$

Eq. 2

where, NDVI is the normalized difference vegetation index $(-1 \leq N D V I \leq 1)$, NIR is the near infrared reflectance at $780 \mathrm{~nm}$ and RED is the red reflectance $(670 \mathrm{~nm})$; and (ii ) chlorophyll vegetation index using the Red Edge (CIRE) developed by Gitelson et al., (2003, 2005), described as:

$$
C I R E=\left[\frac{\rho N I R}{\rho \operatorname{RedEdge}}-1\right]
$$

where, CIRE is the chlorophyll index using the Red Edge $(0 \leq C I R E \leq 2), N I R$ is the near infrared reflectance $(780 \mathrm{~nm})$ and Red Edge is the reflectance in the transition region between RED and NIR, given by CropCircle ${ }^{\circledR}$ at $730 \mathrm{~nm}$. The criteria for choosing these VIs was guided from pioneering studies by Gitelson et al., (1996) that showed the advantages using the red edge band to create vegetation indices. Currently, NDVI is one of the most used VIs worldwide to monitor and analyze, as well as, mapping physiological and biophysical crops characteristics. In spite of NDVI intensive use, several authors have reported NDVI 
limitations due to readings saturation for huge canopy coverage, in other words, when the leaf area index (LAI) of the crop exceeds a certain limit (Gitelson, 2004).

Virtual reference approach proposed by Holland \& Schepers (2013) was used for the inference of the N-rich VI index. This technique uses a sensor algorithm designed for making in season $\mathrm{N}$ recommendations from active crop canopy sensor data. The procedure is to divide measured values of optical sensors by those measured in a well-fertilized plot without $\mathrm{N}$ limitations. This algorithm is sensitive to local conditions because it references a satisfactorily fertilized part of the field at the time of sensing to calculate a Nitrogen Sufficiency Index (NSI), and consequently uses different strategies on establishing a field reference.

That index is developed cooperatively with producers, which have an opportunity to incorporate their experiences by suggesting an optimum $\mathrm{N}$ rate. This concept assumes that in a histogram that the frequency of sensor readings in a population of plants that did not receive $\mathrm{N}$ input. At the time of sensing and in-season $\mathrm{N}$ application, a representative field transect is scanned. The histogram is automatically generated and the 95th percentile vegetative index value is extracted as the reference (Holland and Schepers 2013). This value corresponding to $95 \%$ of the cumulative frequency of VI data.

The authors explain that the virtual reference approach is easier to implement, considering practical adoption, since you do not need to implement $\mathrm{N}$ rich strip in the field being prone to place a $\mathrm{N}$ rich strip on the wrong zone in the field introducing bias in the NSI.

This approach can be applied in two different ways. The first, based on previous mapping of the spatial variability using sensors on board of self-propelled vehicles or motorcycles, called "drive-first", generating the histogram and later the reference VI. In the other way, called "drive-and-apply", the sensor is embedded in machinery capable of realtime variable rate application, generating and continuously updating the histogram from readings collected in real-time while the machine in moving.

Again, all on farm precision experimentation conducted used the methodology proposed by Schepers et al., (1992), which normalizes the sensed VI by an average VI derived from a $\mathrm{N}$ rich plot, and the virtual reference methodology proposed by Holland \& Schepers (2013) was used for $\mathrm{N}$ rich average inference.

All data were submitted to descriptive statistical analysis, adjusting quadratic regression models for the variables of interest. 


\section{Results and discussion}

The VI readings collected during the four years of experiment were compiled to evaluate the VI sensitivity in identifying the $\mathrm{N}$ status variability in cotton. The NDVI showed insensitivity in differentiating $\mathrm{N}$ doses at advanced crop phenological stages, with asymptotic saturation of values above 0.8 (Figure 1), corroborating the results obtained by Gitelson (2004) for soybean, corn and wheat. This is explained by the non-linear relationship of NDVI with biophysical characteristics such as leaf area index (LAI) and biomass, asymptotically saturating under moderate to high biomass conditions (Gitelson et al., 1996; Myneni et al., 1997).

Considering the composition of the NDVI it was observed that the reflectance in the red region $(\rho R E D)$ is not responsive when the LAI exceeds 2, while the near infrared reflectance $(\rho N I R)$ continues to respond significantly to changes in vegetation density from moderate to high in crops (LAI superior to 2). However, this better sensitivity of $\rho N I R$ has little effect on NDVI values since $\rho$ NIR exceeds $30 \%$, causing NDVI insensitivity to changes in chlorophyll contents or $\mathrm{N}$ rates.

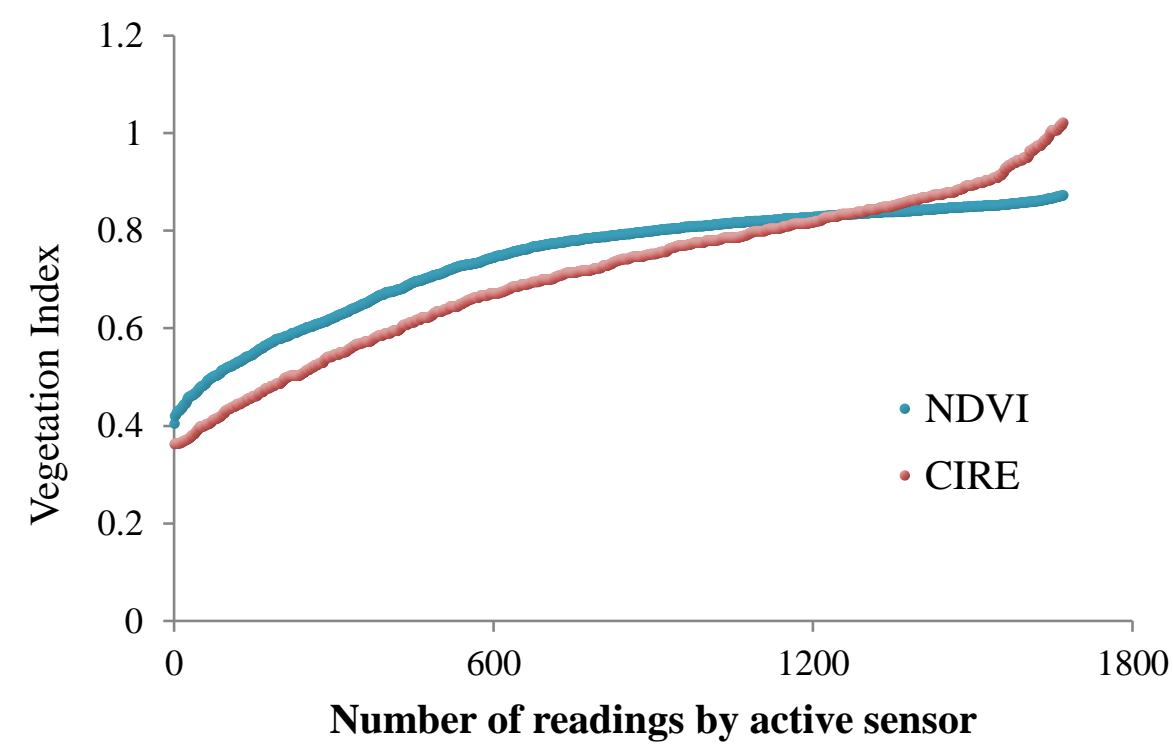

Figure 1. NDVI saturation in cotton illustrated by readings values, collected with an active canopy sensor during the four seasons (2015, 2016, 2017 and 2018). 
The chlorophyll index based on the Red Edge band (CIRE) was responsive to differentiate chlorophyll contents or $\mathrm{N}$ rates throughout the majority of crop development when $\mathrm{N}$ is being absorbed, as it does not present saturation of readings under conditions of high LAI or biomass, being the most suitable for evaluating the nutritional status of $\mathrm{N}$ in cotton (Figure 1) for variable rate purposes. For this reason, the algorithms proposed in this work were based on the CIRE vegetation index.

Sensor readings were carried out in different commercial plots, under different management conditions, different varieties, plant height, disease pressure, soil types, looking for maximum variability in readings under real cotton production conditions in 2015. From all data, $50 \%$ of the sensor readings were used to generate the algorithm and the other $50 \%$ were used for the validation of the proposed algorithm.

From the frequency distribution histogram (Figure 2) generated with the CIRE values collected during the season in a "drive-first" system, the value of 0.89 corresponding to $95 \%$ of the accumulated frequency was extracted, being determined via linear interpolation .

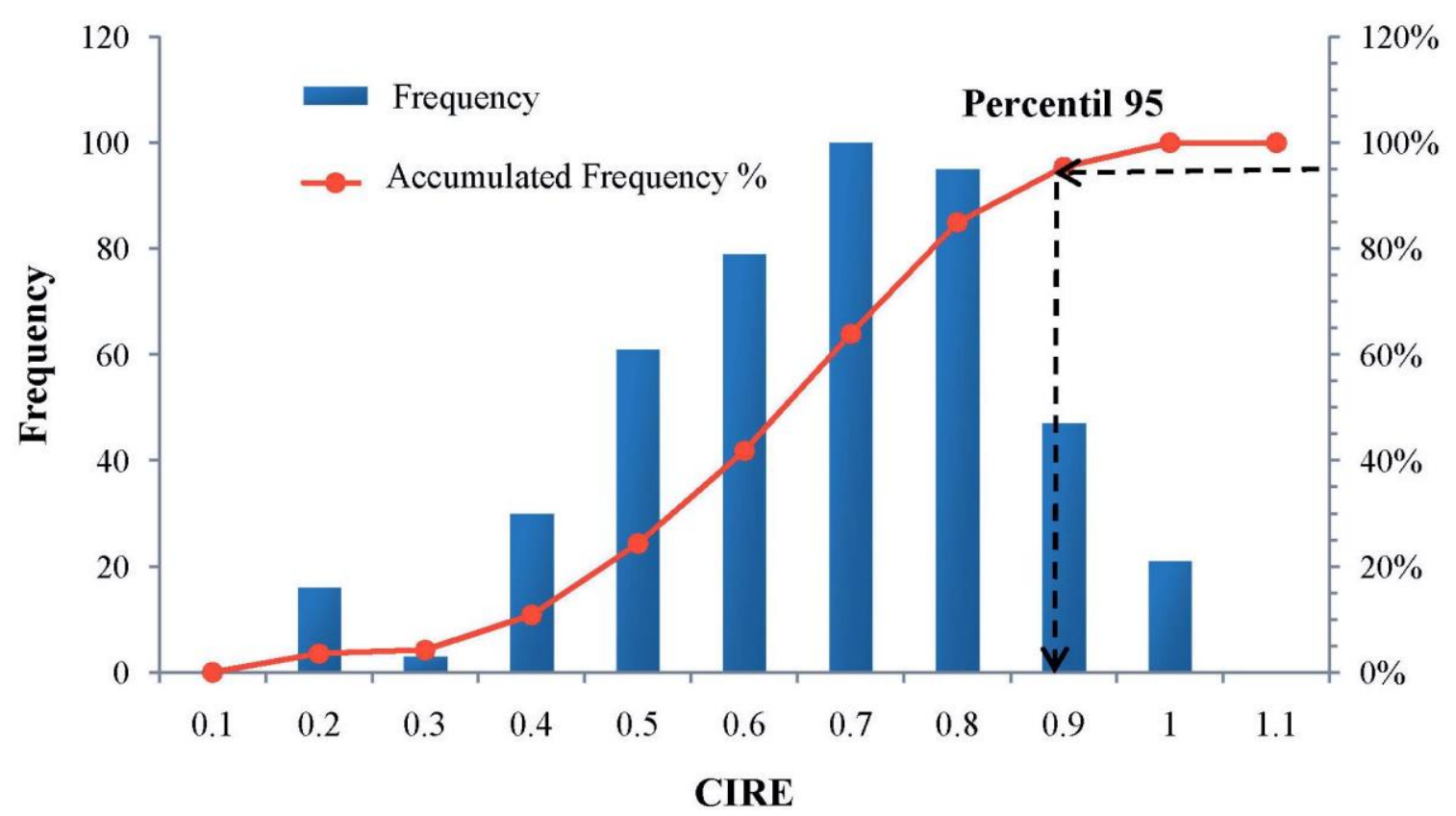

Figure 2. Frequency distribution and cumulative frequency for chlorophyll vegetation index using the Red Edge (CIRE), obtained in commercial crops of partners in 2015 season.

The concept of virtual reference was proposed to overcome the producer needs in establish $\mathrm{N}$ rich strips in their fields, making this practice easier in terms of practical adoption in the field. However, limitations and precautions associated with the use of remote sensing also apply to the virtual reference approach for data interpretation, as crops growing under 
conditions of inherent environmental or water stress have effects on canopy reflectance, not reflecting actual status of $\mathrm{N}$. In addition, the virtual reference of an area where other factors are not satisfactory, such as lack of other nutrients and water, weed infestation, pesticide phytotoxicity, the value corresponding to non $\mathrm{N}$ deficiency can be masked and fertilizer rates can be overapplied.

The virtual reference value extracted from the histogram was used to normalize the sensor readings, thus transforming the values into SI, now treated as a nitrogen sufficiency index (NSI). For example: a sensed CIRE value of 0.85 divided by 0.89 (virtual reference) results in an NSI of 0.95 .

For the algorithm parameterization, the $\mathrm{N}$ rate with the highest average cotton yield potential in commercial plots, adjusting a yield response curve based on $\mathrm{N}$ rate, indicating that the better yield (221@ $\mathrm{ha}^{-1}$ ) occurred at the highest dose of $180 \mathrm{~kg} \mathrm{~N} \mathrm{ha}^{-1}$ (Figure 3). The average vegetation index value sensed at this $\mathrm{N}$ rate, corresponde to $2.8 \%$ lower than the value obtained using the virtual reference concept, which corroborates Holland \& Schepers (2013) who found vegetation index values derived from a $\mathrm{N}$ rich strip less than $5 \%$ when compared to values obtained using virtual reference, indicating that the value corresponding to $95 \%$ of the accumulated frequency comes from plants with $\mathrm{N}$ sufficiency condition, even without receiving $\mathrm{N}$ starter $\mathrm{N}$ supply.

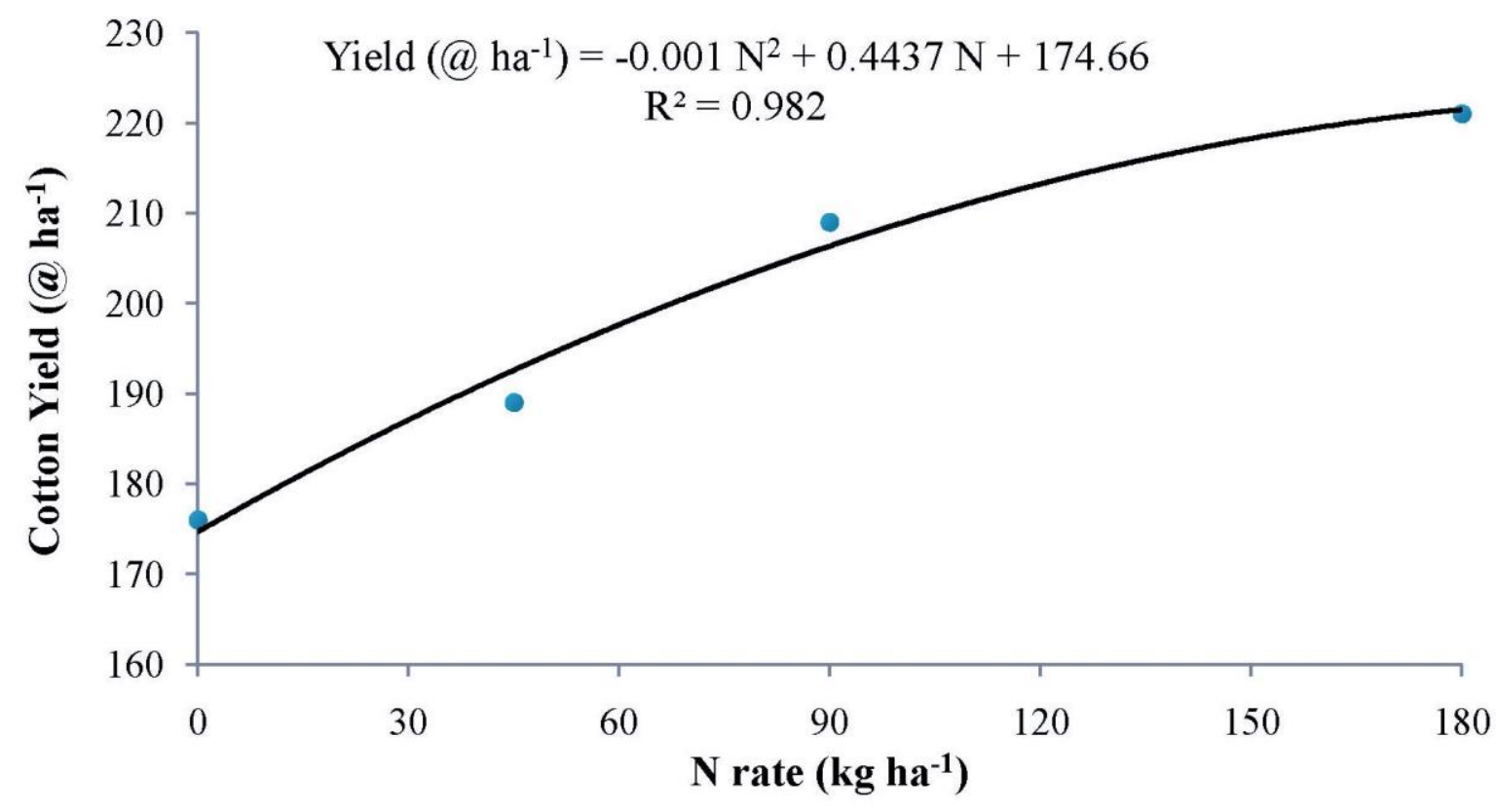

Figure 3. Average cotton yield in response to $\mathrm{N}$ rates in commercial fields on farm. 
Based on the sensor readings transformed into NSI and parameterized by the N rate that maximized cotton yield, the $\mathrm{N}$ sufficiency response curve of the crop was generated, obtaining the best fit to the quadratic model (Figure 04). This response curve is interpreted as being how much $\mathrm{N}$ the plant is supplied at the time of sensor reading in relation to the greatest crop yield when sufficient of $\mathrm{N}$ was applied.

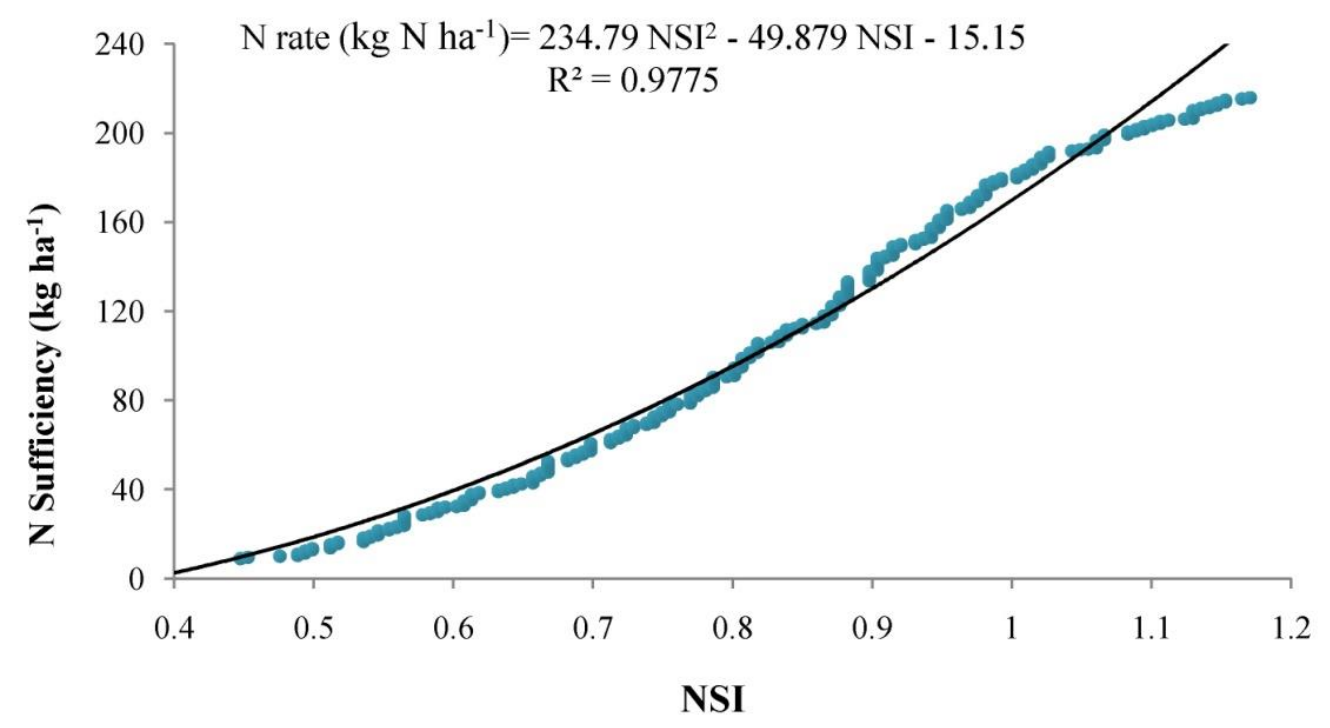

Figure 4. N sufficiency, based on a virtual reference for cotton in a commercial production system.

Making the difference between the $\mathrm{N}$ rate that maximized cotton yield ( $180 \mathrm{~kg} \mathrm{~N} \mathrm{ha}^{-1}$ ) with the $\mathrm{N}$ content estimated in the plant by the sensor, we got the algorithm for determining the best $\mathrm{N}$ dose to be applied in top dressing, as showed in Figure 5, where one graph is the inverse. In summary, the algorithm assumes that the NSI read by the sensor predicts the N nutritional status of the crop and, by difference, the algorithm asks for the remaining $\mathrm{N}$ to be applied to reach $180 \mathrm{~kg} \mathrm{~N} \mathrm{ha}^{-1}$.

The quadratic adjustment that describes the relationship between $\mathrm{N}$ rates and NSI corroborates with the results obtained by Varvel et al. (2007) and Shiratsuchi et al., (2014) for corn in a commercial production system.

To validate the proposed algorithm for $\mathrm{N}$ recommendation in commercial areas, the equation for $\mathrm{N}$ recommendation was applied to the remaining half of the readings normalized by the virtual reference value and transformed into NSI. On average the $\mathrm{N}$ recommendation algorithm for commercial areas underestimates the $\mathrm{N}$ rates by $1.45 \mathrm{~kg} \mathrm{~N}^{-1}$ (Figure 6), showing a low error. 


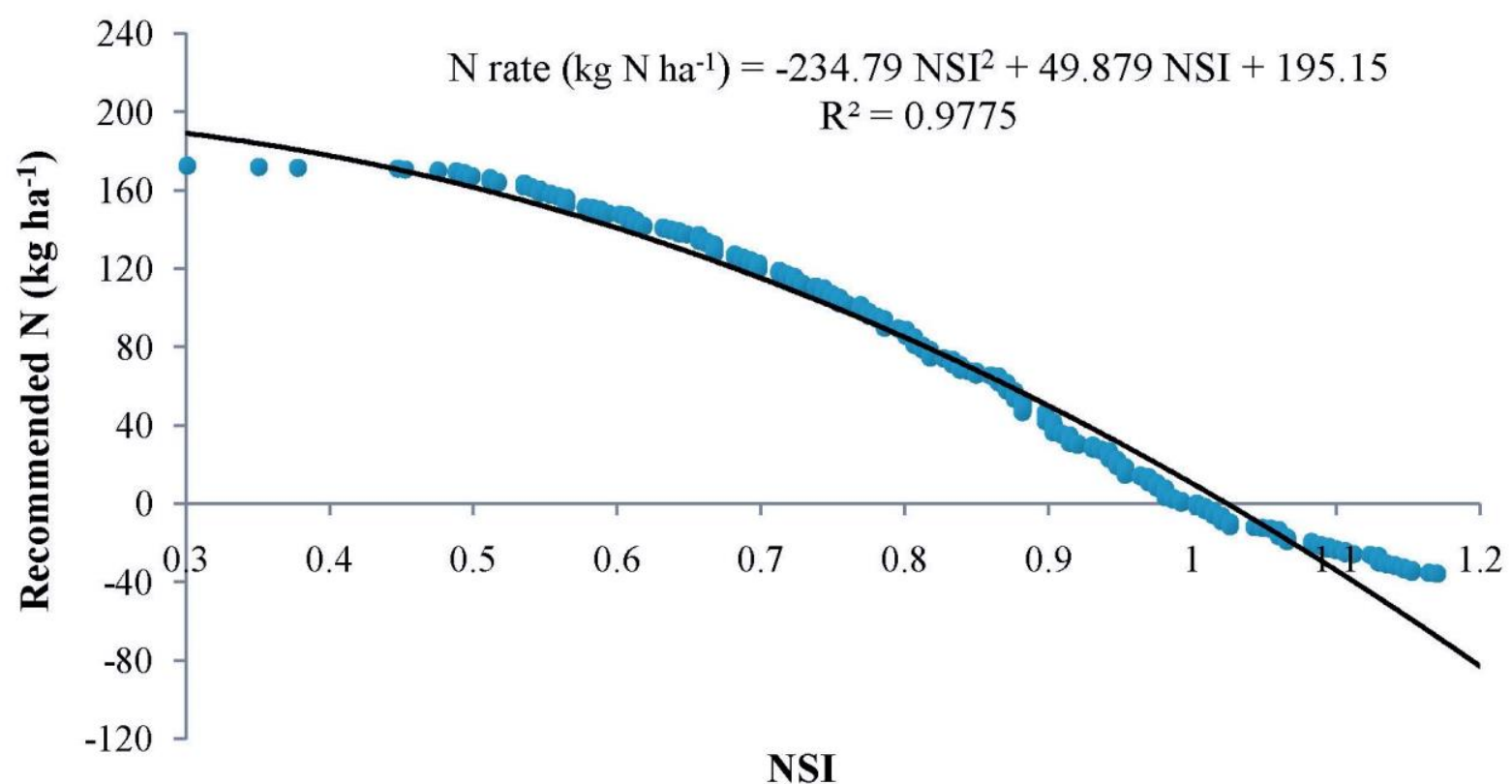

Figure 5. Virtual reference N-based recommendation algorithm for cotton in commercial production system.

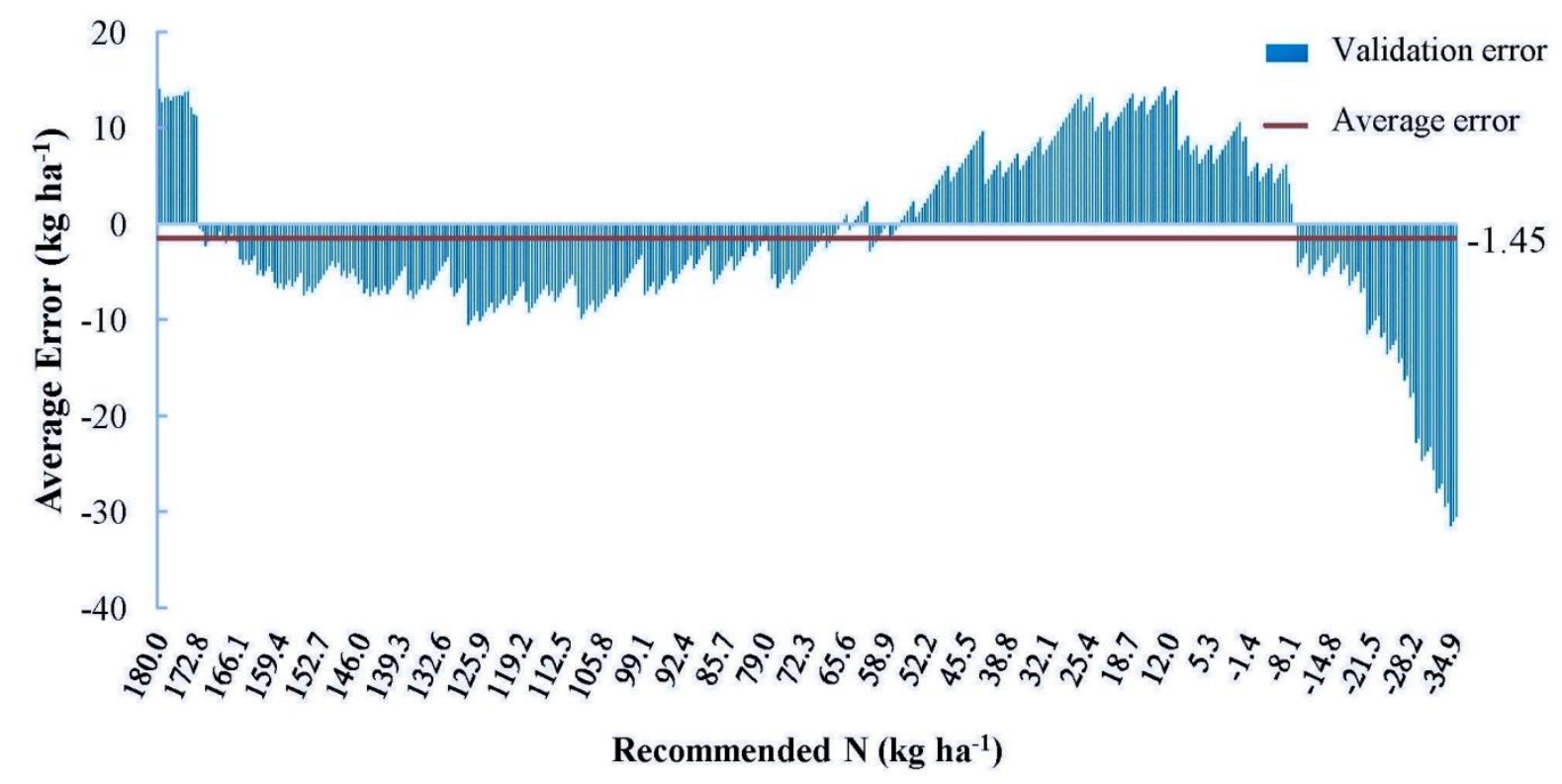

Figure 6. Validation error of the $\mathrm{N}$ recommendation algorithm for cotton in a commercial production system.

Future studies using this on farm precision experiment approach will be necessary, looking for the maximum variability of readings in real cotton production for a greater refinement of the proposed algorithm. However, it is important to report that the present procedure has easy adoption and can be developed under specific conditions of spatial variability and production system adopted by the producer. This work suggested two second 
degree equations, but is important to keep in mind that there is no universal formula for all environment conditions, and so it is important to have a simple formulation that can be translated and implemented by consultants or producers.

The methodology proposed from Schepers et al., (1992) was also used for the algorithm generation in experimental fields in Embrapa experimental farm, with data normalization and the approach to determine the N-rich strip sensor average proposed by Holland \& Schepers (2013).

Sensor readings collected at advanced phenological stages during the 3 years of the experiment were used to ensure the effect of $\mathrm{N}$ rates, where the highest standard deviations were found after 100 days after emergence (DAE), with 120 being chosen DAE due to a stabilization of the deviations. Calibration and validation used $50 \%$ data split as the commercial fields.

From the frequency distribution histogram (Figure 7) generated with the CIRE values collected during the seasons in the "drive-first" system, the value of 0.70 corresponding to $95 \%$ of the accumulated frequency was extracted, being determined via linear interpolation.

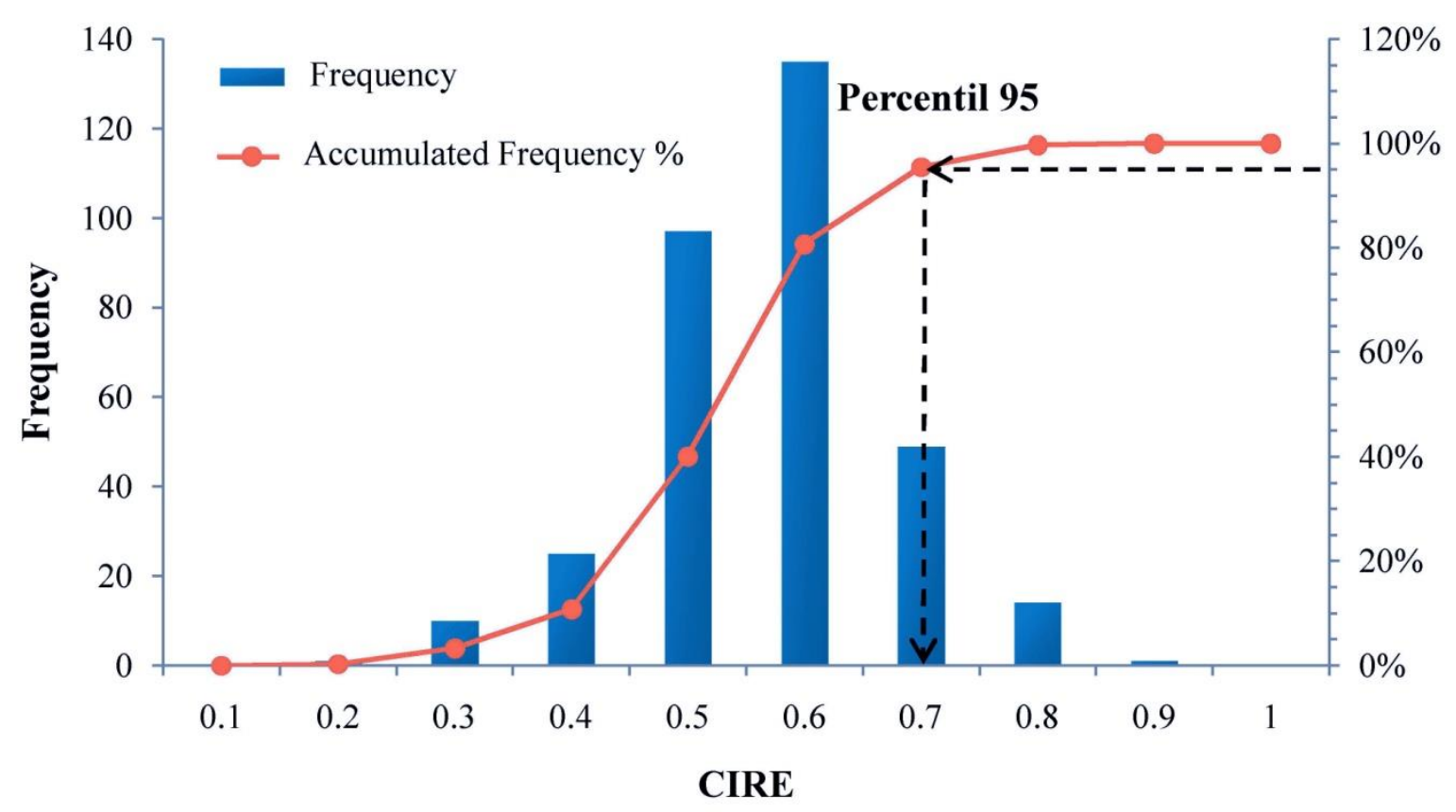

Figure 7. Frequency distribution and cumulative frequency for chlorophyll vegetation index using the Red Edge (CIRE), obtained in experimental area at SINOP, MT in three seasons.

The virtual reference value extracted from the histogram was used to normalize the sensor readings using the same procedure for the commercial sites. For the algorithm 
parameterization, it was selected the $\mathrm{N}$ rate with the highest average yield potential of cotton during the 3 years of the experiment, adjusting a yield response curve based on $\mathrm{N}$ rate, indicating which rate provide the highest yield, that in this case was $178 @$ ha $^{-1}$, occurred at the highest applied dose $\left(180 \mathrm{~kg} \mathrm{~N} \mathrm{ha}^{-1}\right)$, as presented in Figure 8.

The average sensor CIRE index value at the dose $180 \mathrm{kgN} \mathrm{ha}^{-1}$ corresponds to 0.68 , being $2.8 \%$ lower than the value obtained with the concept of virtual reference, which corroborates to Holland \& Schepers (2013).

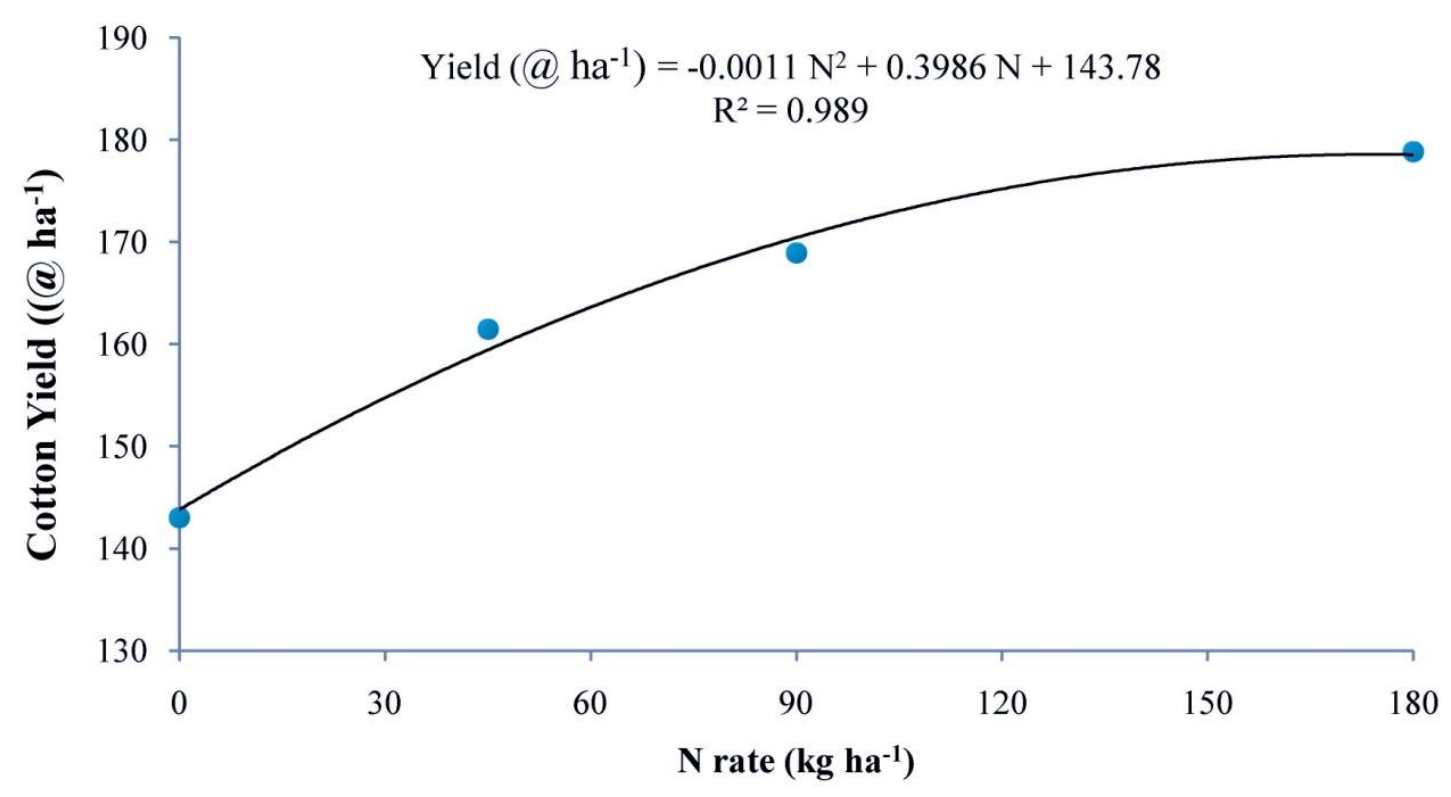

Figure 8. Average cotton yield in response to nitrogen rates during the 3 years of study $(2016,2017$ and 2018) in experimental plots.

The N-sufficiency response curve for cotton was generated based on readings obtained by sensor, transformed into Nitrogen Sufficiency Index (NSI). After that, the values were parameterized by the rate that maximized cotton yield. Best fits were obtained using quadratic model, with coefficient of determination $\left(\mathrm{R}^{2}\right)$ exceeding 0.94, as showed in Figure 9. This response curve is interpreted as the $\mathrm{N}$ supply during sensor reading in relation to the crop's highest yield potential $\left(180 \mathrm{~kg} \mathrm{~N} \mathrm{ha}^{-1}\right)$. 


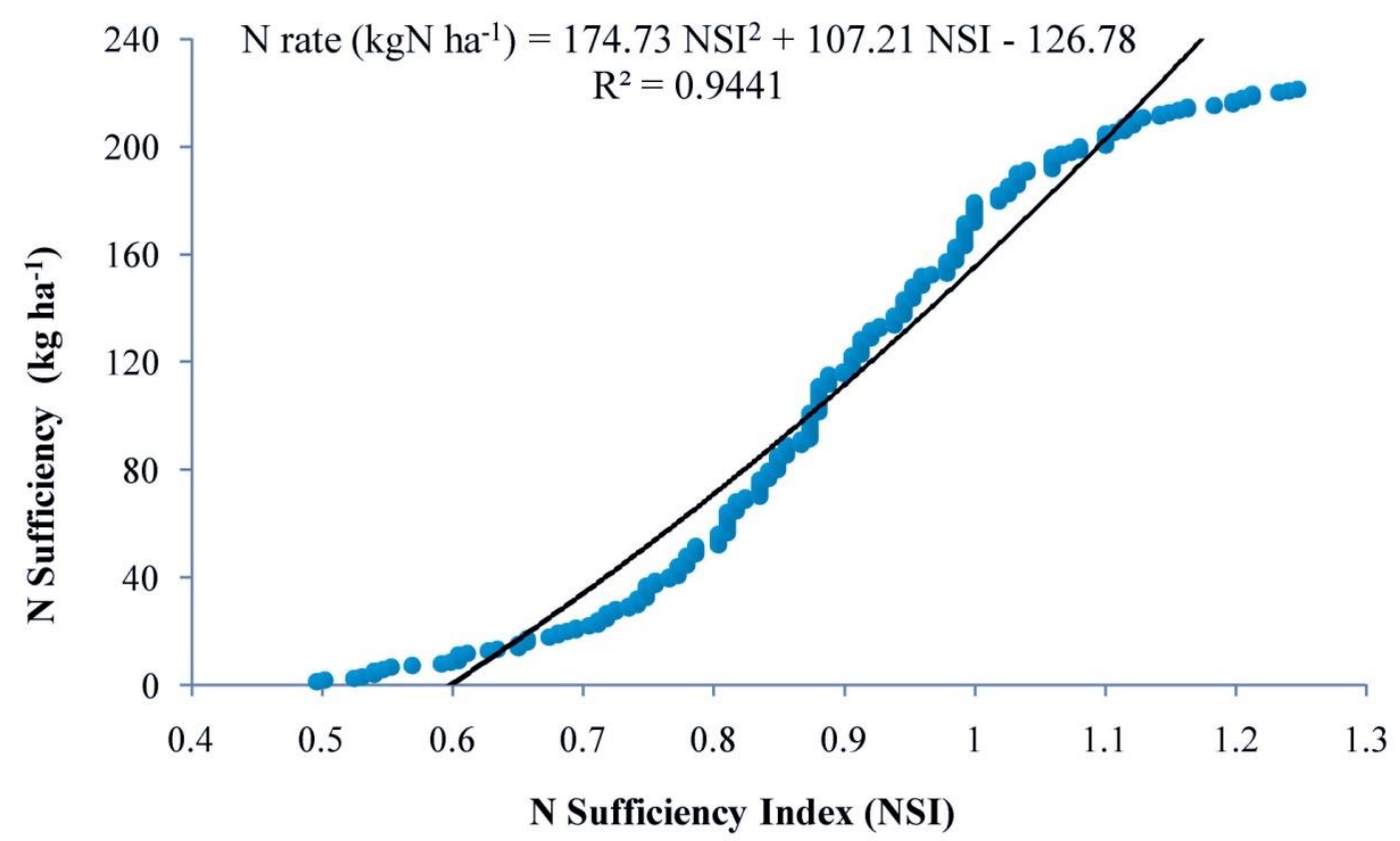

Figure 9. Nitrogen $(\mathrm{N})$ sufficiency algorithm based on virtual reference for cotton in experimental plots.

To maximize cotton yield, the required $\mathrm{N}$ rate is calculated subtracting the maximum value (180 $\left.\mathrm{kg} \mathrm{N} \mathrm{ha}^{-1}\right)$, from the applied dose in the experiment, as represented in graph on Figure 10. In summary, the algorithm assumes that the NSI sensor read predicts the N nutritional status of the crop and, by difference, the algorithm asks for the remaining $\mathrm{N}$ to be applied to reach $180 \mathrm{~kg} \mathrm{~N} \mathrm{ha}^{-1}$.

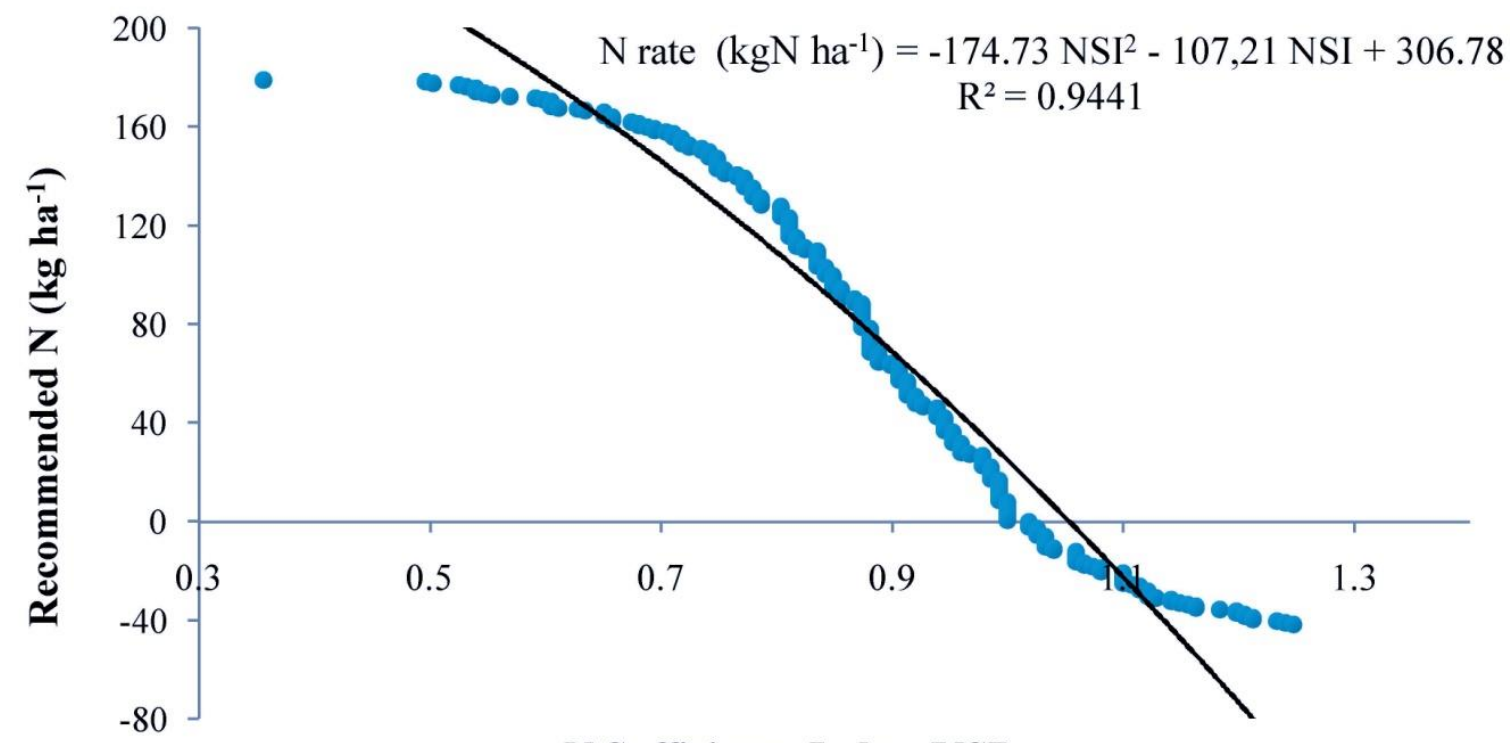

N Sufficiency Index (NSI)

Figure 10. Recommended Nitrogen $(\mathrm{N})$ algorithm based on virtual reference for cotton in experimental plots at SINOP, MT, Brazil. 
It should be noted that one of the great advantages of this approach in relation to the $\mathrm{N}$-rich strip mounted in the field is the irrelevance of prior field knowledge of the spatial and temporal variability, integrating the effects of climate, soil and culture into the sensor reading. The same way to validate the $\mathrm{N}$ recommendation algorithm proposed in this work but now for experimental plots, the $\mathrm{N}$ recommendation equation was applied to the remaining half of the sensor readings normalized by the virtual reference value and transformed into NSI. On average, the $\mathrm{N}$ recommendation algorithm for experimental plots overestimates the dose by $9.40 \mathrm{kgN} \mathrm{ha}^{-1}$ (Figure 11).

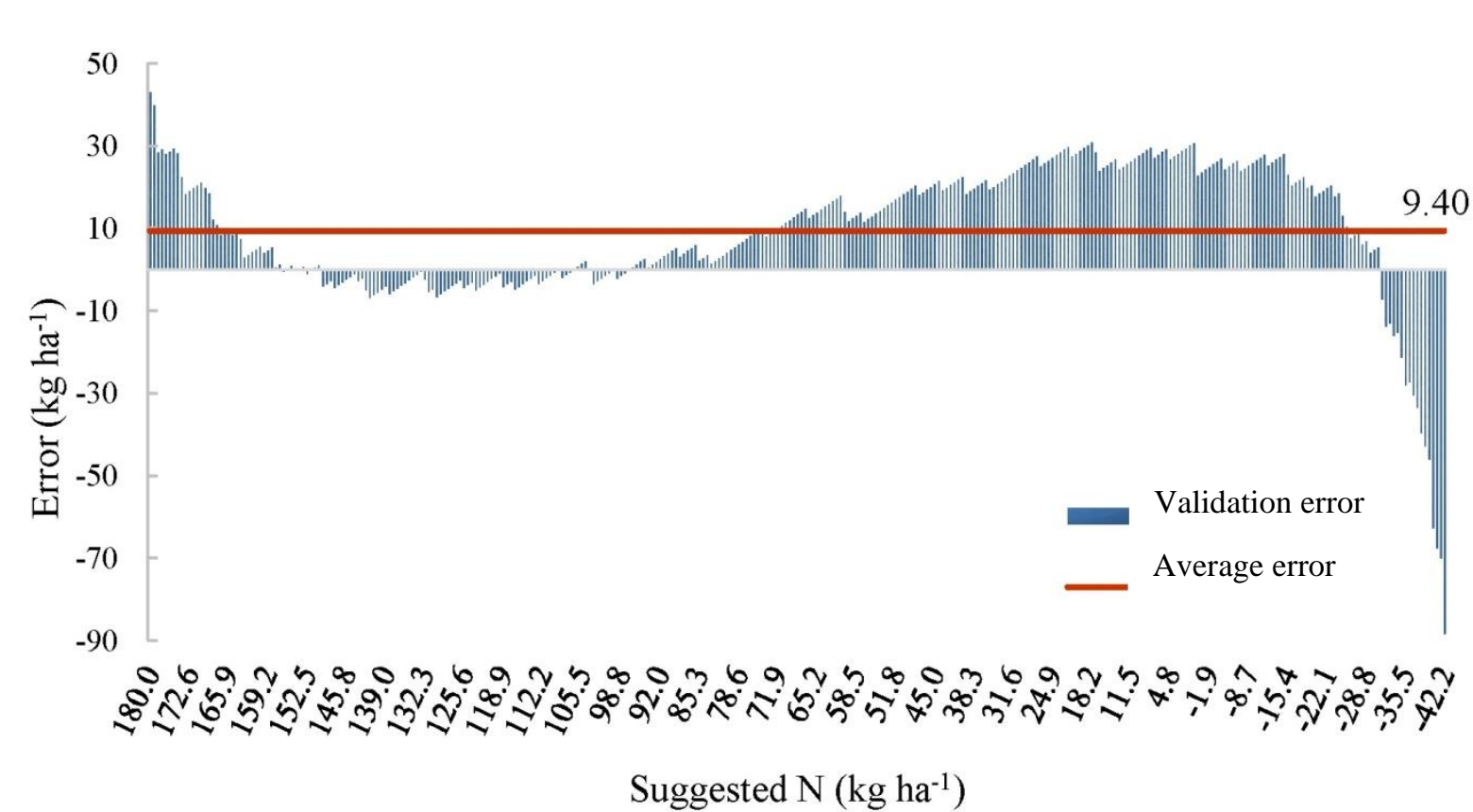

Figure 11. Validation error of the nitrogen $(\mathrm{N})$ recommendation algorithm for cotton in experimental plots.

The algorithms proposed in this work are sensitive to the targeted production potential for the $\mathrm{N}$ rates established of $180 \mathrm{kgN} \mathrm{ha}^{-1}$. Therefore, for higher or lower $\mathrm{N}$ rates that maximizes the cotton yield potential, new formulations should be generated following the same methodologies used in this study.

It is important to note that these algorithms calculate the total $\mathrm{N}$ to be applied to crop, so if $\mathrm{N}$ is used in the base during planting, this rate must be subtracted from the total, that in this case is 180 . For example: $30 \mathrm{~kg} \mathrm{~N} \mathrm{ha}^{-1}$ were applied at planting and the algorithm asks for a dose of $120 \mathrm{~kg} \mathrm{~N} \mathrm{ha}^{-1}$, then a dose of $90 \mathrm{~kg} \mathrm{~N} \mathrm{ha}^{-1}$ should be applied.

In order to evaluate this performance, we applied the $\mathrm{N}$ recommendation algorithm generated in experimental plots in the sensor data in commercial plots in 2015 to estimate the 
$\mathrm{N}$ rate to be applied, this validation overestimated on average only $24.34 \mathrm{~kg} \mathrm{~N}$ ha-1 (Figure 12).

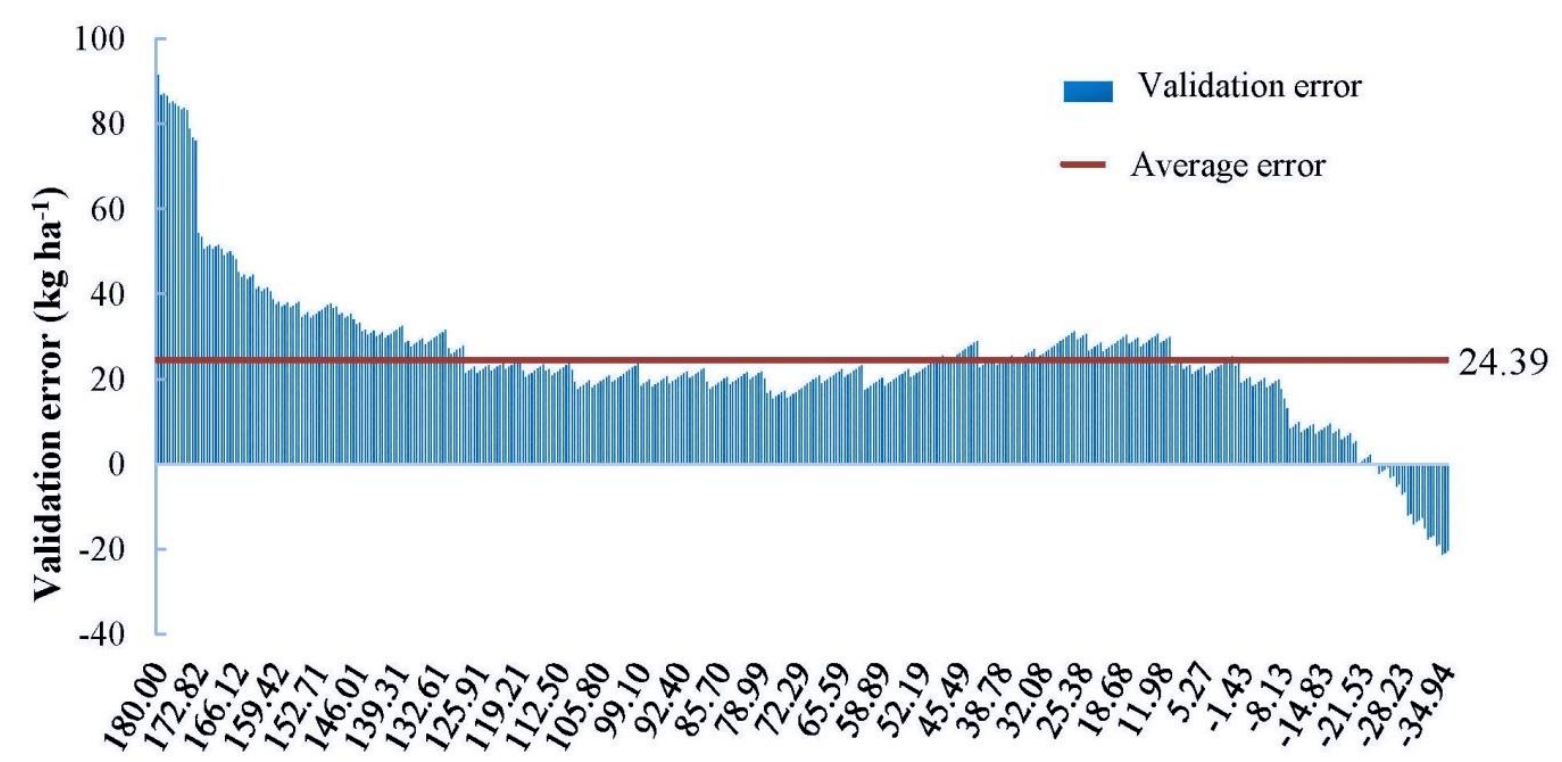

\section{Recommended N (kg ha-1)}

Figure 12. Validation error of the $\mathrm{N}$ recommendation algorithm in experimental plots applied to sensor data in commercial crops.

In summary, the algorithm generated in experimental plots overestimates the rates when applied to data collected from commercial crops, in this case reaching up to $91.61 \mathrm{kgN}$ $\mathrm{ha}^{-1}$ (Figure 12). This is due to the low representation of the location chosen as a reference in relation to the commercial area to be applied, given the difference in region, climate, soil, variety, pest pressure, diseases, among others.

\section{Conclusion}

Two algorithms for variable rate $\mathrm{N}$ fertilization for cotton were developed, namely: $\mathrm{N}$ recommendation algorithm for cotton in commercial production system: $\mathrm{N}$ rate $\left(\mathrm{kgN} \mathrm{ha}^{-1}\right)=-$ 234.79 $\mathrm{NSI}^{2}+49.879 \mathrm{NSI}+195.15, \mathrm{R}^{2}=0.97$; and $\mathrm{N}$ recommendation algorithm for cotton grown in experimental conditions: $\mathrm{N}$ rate $\left(\mathrm{kgN} \mathrm{ha}^{-1}\right)=-174.73 \mathrm{NSI}^{2}-107.21 \mathrm{NSI}+306.78$, $\mathrm{R}^{2}=0.94$. Considering the practical adoption, the approach explored in this work is easy, due to the simplicity of determination under proper conditions, allowing the producer to establish his own algorithm for localized conditions, reducing eventual costs of $\mathrm{N}$ rich strip implementation in the field that requires expenses with nitrogen fertilizers, and tractor operation, labor and time for application. 
In this study, a large discrepancy was noticed between data collected in small plots established in an experimental station compared to data obtained on commercial farms, generating very different formulations regarding the $\mathrm{N}$ rates to be applied in real time or mapbased by sensors. Therefore, the direct use of the formulations obtained in this work in either of the two approaches can result in under- or over-estimation of the appropriate rates. Therefore, it is necessary to generate an own algorithm for each farm condition. Despite the fact that errors can be high when a experimental equation is used on producers conditions, this error will be much smaller than to use imported algorithms from other countries.

Although it is not possible to control all the variables that interfere with the cotton demand for $\mathrm{N}$, the main conclusion is that the use of large plots associated with the virtual reference approach proved to be a much more practical method, facilitating the adoption by the producers, with easy equation adjustment because of the large number of samples and ease extrapolation for different conditions on the farm. And the common sense to use the equation generated from farmers sites and not the equation generated from experimental station. Take home message is to use virtual reference approach and generate the simple equation in your farm condition avoiding the use of "one size fits all magic formulations".

\section{Acknowledgements}

The authors would like to thank Brazilian Agricultural Research Corporation (Embrapa); Federal University of Mato Grosso (UFMT) and producers for financial support and constant interest on this subject that is needed for adoption of proximal remote sensing on cotton production. This paper is part of the master thesis of Jonnas De Marchi that is the first author that expended long hours scanning fields and supporting our team when Dr. Luciano Shiratsuchi was a researcher at Embrapa.

\section{References}

ANSELMO, J. L.; HOLANDA, H. V.; KANEKO, F. H.; ALVES, L. A.; LOURENÇO, P. H. F. N.; LEAL, A. J. F.; RICIERI, A. D.Estimativa do custo de produção do algodão em caroço, na região dos chapadões - Safra 2010/11. In: CONGRESSOBRASILEIRO DO ALGODÃO, 8.; COTTON EXPO, 1., 2011, São Paulo. Evolução da cadeia para construção de um setor forte: Anais. Campina Grande, PB: Embrapa Algodão, 2011. p 1774 -1781.

ANTILLE, D. L.; MOODY, P. W. Nitrogen use efficiency indicators for the Australian cotton, grains, sugar, dairy and horticulture industries. Environmental and Sustainability Indicators, v.10, p 02-10, 2021. DOI: https://doi.org/10.1016/j.indic.2020.100099. 
BELl, M.J.; MOODY, P.; SAlTer, B.; CONNEllan, J.; GARSIDE, A.L., Agronomy and physiology of nitrogen use in Australian sugarcane crops. In: Bell, M.J. (Ed.). A Review of Nitrogen Use Efficiency in Sugarcane. Sugar Research Australia, Indooroopilly, QLD, Australia, p. 75-109. 2014.

BLACKMER, T. M.; SCHEPERS. J. S.; VARVEL, G. E.; WALTER-SHEA, E. A. Nitrogen deficiency detection using reflected shortwave radiation from irrigated corn canopies. Agronomy Journal, Madison, v. 88, p. 1-5, 1996.

CANTARELLA, H. Nitrogênio. In: NOVAIS, R. F.; ALVAREZ, V. H.; BARROS, N. F.; FONTES, R. L. F.; CANTARUTTI, R. B.; NEVES, J. C. L. (Ed).Fertilidade do solo. Viçosa: SBCS, 2007. p. 375-470.

CONNELlAN, J.F.; DEUTSCHENBAUR, J. Nitrogen Accumulation in Biomass and its Partitioning in Sugarcane Grown in the Burdekin. Proceedings of the Australian Society of Sugar Cane Technology, v.38, p.72-80. 2016

DEBAEKE, P.; ROUET, P.; JUSTES, E. Relationship between the normalized SPAD index and the nitrogen nutrition index: Application to durum wheat. Journal Plant Nutrition. 29:75-92, 2006.

EMBRAPA - Empresa Brasileira de Pesquisa Agropecuária. Algodão: Tecnologia de produção. Dourados: EmbrapaAgropecuária Oeste, 2001. 296p.

GITELSON, A. A. Wide Dynamic Range Vegetation Index for Remote Quantification of Crop Biophysical Characteristics. Journal of plant physiology, Vol. 161, 165-173. 2004.

GITELSON, A. A.; GRITZ, U.; MERZLYAK, M. N. Relationships between leaf chlorophyll content and spectral reflectance and algorithms for no-destructive chlorophyll assessment in higher plant leaves. Journal of plant physiology, 160, 271-282. 2003.

GITELSON, A. A.; KAUFMAN, Y.; MERZLYAK, M. N. Use of green channel in remote sensing of global vegetation from EOS-MODIS. Remote Sensing of Environment, v. 58, p. 289-298, 1996.http://dx.doi.org/10.1016/S0034-4257(96)00072-7.

GITELSON, A. A.;MERZLVAK, M. N.; LICHTENTHALER, H.K.. Detection of red edge position and chlorophyll content by reflectance measurements near $700 \mathrm{~nm}$. JournalofPlantPhysiology, 148(34), 501-508. 1996.

GITELSON, A. A.; VINA, A.; CIGANDA, V.; RUNDQUIST, D. C.; ARKEBAUER, T.J. Remote estimation of canopy chlorophyll content in crops. Geophysical Research Letters32: 4-7. 2005.

HABOUdANE, D.; MILlER, J. R.; PATTEY E.; ZARCO-TEJADA, P. J.; STRACHAN, I. B. Hyperspectral vegetation indices and novel algorithms for predicting green LAI of crop canopies: 
Modeling and validation in the context of precision agriculture. Remote Sensing of Environment, v. 90, p. 337-352, 2004. http://dx.doi.org/10.1016/j.rse.2003.12.013

HOLLAND, K. H. Sensor-based chemical management for agricultural landscapes. U.S. Patent \#7,723,660. Issue May 25, 2009.

HOLLAND, K. H; SCHEPERS, J. S. Derivation of a variable rate nitrogen application model for inseason fertilization of corn. Agronomy Journal. 102; 1415-1424, 2010.

HOLLAND, K. H.; SCHEPPERS, J. S. Use of a virtual reference concept to interpret active crop canopy sensor data. Precision Agriculture, v. 14, p. 71-85, 2013.

HUSSAIN, F.; BRONSON, K. F.; YADVINDER, S.; BIJAY, S.; PENG, S. Use of chlorophyll meter sufficiency indices for nitrogen management of irrigated rice in Asia. Agronomy Journal. 92:875-879, 2000.

KITCHEN, N. R.; SUDDUTH, K. A.; DRUMMOND, S. T. Is a nitrogen-rich reference needed for canopy sensor-based corn nitrogen applications?. In: INTERNATIONAL CONFERENCE ON PRECISION AGRICULTURE, 10., 2010, Denver. Proceedings... Monticello: ISPA, 2010. 1 CDROM.

MYNENI, R. B.; NEMANI, R. R.; RUNNING, S. W. Estimation of global leaf area index and absorbed PAR using radiative transfer models. IEEE Trans. Geosci. Remote Sensing. 33: 1380-1393. 1997.

PETERSON, T.A.; BLACKMER, T. M.; FRANCIS, D. D.; SCHEPERS, J. S. Using a chlorophyll meter to improve N management. NebGuide G93-1171-A. University of Nebraska Ext., Lincoln, 1993.

RAUN, W. R.; SOLIE, J. B.; MAY, J.; ZHANG, H.; KELLY, J.; TAYLOR, R. K.; ARNALL, D. B.; MONASTERIO, I. O. Nitrogen rich strips for wheat, corn and other crops. Publications E-1022. Stillwater: Oklahoma State University Extension. 2010.

RAUN, W. R.; SOLIE, J. B.; TAYLOR, R. K.; ARNALL, D. B.; MACK, C. J.; EDMONDS, D. E. Ramp calibration strip technology for determining midseason nitrogen rates in corn and wheat. Agronomy Journal, Madison, v. 100, n. 4, p. 1088-1093, 2008.

ROSOLEM, C. A. Problemas em nutrição mineral, calagem e adubação do algodoeiro. Informações Agronômicas, Piracicaba-SP, n. 95, 2001. 17 p. (Encarte Técnico).

ROUSE, J. W.; HAAS, R. H.; SCHELL, J. A.; DEERING, D. W.; HARLAN, J. C. Monitoring the vernal advancement and retrogradation (green wave effect) of natural vegetation, Texas: Texas A\&M University, 1974. (Type III final. NASA/GSFC). 
SANTOS, H. G.; JACOMINE, P. K. T.; ANJOS, L. H. C.; OLIVEIRA, V. A.; LUMBRERAS, J. F.; COELHO, M. R.; ALMEIDA, J. A.; CUNHA, T. J. F.; OLIVEIRA, J. B. Sistema brasileiro de classificação de solos. $3^{\mathrm{a}}$.ed. rev. Brasília, DF: Embrapa, 2013.

SCHEPERS, J. S.; FRANCIS, D. D.; VIGIL, M.; BELOW, F. E. Camparison of corn leaf nitrogen concentration and chlorophyll meter readings. Communications in Soil Science and Plant Analysis. v. 23, n. 17-20, p. 2173-2187, 1992.

SHIRATSUCHI, L. S.; BRANDAO, Z. N.; VICENTE, L. E.; VICTORIA, D. de C.; DUCATI, J. R.; OLIVEIRA, R. P. de; VILELA, M. de F. Sensoriamento Remoto: conceitos básicos e aplicações na Agricultura de Precisão.. In: BERNARDI, A. C. de C.; NAIME, J. de M.; RESENDE, A. V. de; BASSOI, L. H.; INAMASU, R. Y. (Ed.). Agricultura de precisão: resultados de um novo olhar. Brasília, DF: Embrapa, 2014.

SHIRATSUCHI, L. S.; VALE, W. G.; MALACARNE, T. J.; SCHUCK, C. M.; SILVA, R. G.; JUNIOR, O. L. O. Algoritmos para aplicações de doses de variáveis de nitrogênio em tempo real para produção de milho safra e safrinha no Cerrado. In: BERNARDI, A. C. C.; NAIME, J. M.; RESENDE, A. V.; BASSOI, L. H.; INAMASU, R. Y. Agricultura de precisão: um novo olhar. Brasília, DF: Embrapa, 2014. p. 226-232.

TARPLEY, L.; REDDY, K. R.; SASSENRATH-COLE, G. F. Reflectance indices with precision and acurracy in prediction cotton leaf nitrogen concentration. Crop Science,

Madison, v. 1. n. 40, p. 1814-1819, 2000.

VARVEL, G. E.; WILHELM, W. W.; SHANAHAN, J. F.; SCHEPERS, J. S. Nitrogen fertilizer applications for corn based on sufficiency index calculations. Agronomy Journal, 99, 701-706, 2007.

ZHU, J.; TREMBLAY, N.; LIANG, Y. Corn Nitrogen Status Indicator Less Affected by Soil Water Content. Agronomy Journal. 103, 809, 2011. 